University of Nebraska - Lincoln

DigitalCommons@University of Nebraska - Lincoln

USDA National Wildlife Research Center - Staff Publications
U.S. Department of Agriculture: Animal and Plant Health Inspection Service

December 2004

\title{
Damage reduction estimates and benefit-cost ratios for feral swine control from the last remnant of a basin marsh system in Florida
}

Richard M. Engeman

USDA-APHIS-Wildlife Services, s_r100@yahoo.com

Henry T. Smith

Florida Department of Environmental Protection, Florida Park Service

Robert Severson

Savannas Preserve State Park

Mary Ann Severson

Savannas Preserve State Park

John Woolard

USDA/APHIS/WS

See next page for additional authors

Follow this and additional works at: https://digitalcommons.unl.edu/icwdm_usdanwrc

Part of the Environmental Sciences Commons

Engeman, Richard M.; Smith, Henry T.; Severson, Robert ; Severson, Mary Ann; Woolard, John ; Shwiff, Stephanie A.; Constantin, Bernice; and Griffin, Daniel , "Damage reduction estimates and benefit-cost ratios for feral swine control from the last remnant of a basin marsh system in Florida" (2004). USDA National Wildlife Research Center - Staff Publications. 334.

https://digitalcommons.unl.edu/icwdm_usdanwrc/334

This Article is brought to you for free and open access by the U.S. Department of Agriculture: Animal and Plant Health Inspection Service at DigitalCommons@University of Nebraska - Lincoln. It has been accepted for inclusion in USDA National Wildlife Research Center - Staff Publications by an authorized administrator of DigitalCommons@University of Nebraska - Lincoln. 


\section{Authors}

Richard M. Engeman, Henry T. Smith, Robert Severson, Mary Ann Severson, John Woolard, Stephanie A. Shwiff, Bernice Constantin, and Daniel Griffin 


\title{
Damage reduction estimates and benefit-cost ratios for feral swine control from the last remnant of a basin marsh system in Florida
}

\author{
RICHARD M. ENGEMAN ${ }^{1 *}$, HENRY T. SMITH ${ }^{2}$, ROBERT SEVERSON $^{3}$, \\ MARY ANN SEVERSON ${ }^{3}$, JOHN WOOLARD ${ }^{4}$, STEPHANIE A. SHWIFF ${ }^{1}$, \\ BERNICE CONSTANTIN ${ }^{4}$ AND DANIEL GRIFFIN ${ }^{3}$ \\ ${ }^{1}$ National Wildife Research Center, 4101 LaPorte Avenue, Fort Collins, CO 80521-2154, USA, ${ }^{2}$ Florida Department of Environmental \\ Protection, Florida Park Service, 13798 SE Federal Highmay, Hobe Sound, FL 33455, USA, ${ }^{3}$ Savannas Preserve State Park, 9551 Gumbo Limbo \\ Lane, fensen Beach, FL 34957, USA, and ${ }^{4}$ USDA/APHIS/WS, 2820 East University Avenue, Gainesville, FL 32641, USA \\ Date submitted: 28 April 2004 Date accepted: 7 September 2004
}

\section{SUMMARY}

The introduction of swine (Sus scrofa) has adversely affected the environment of many natural habitats throughout the world. Basin marshes are dwindling ecosystems in Florida that are especially vulnerable to damage by feral swine. In January 2003, the estimated amount of swine damage to the exposed portion of the last remnant of a basin marsh system in Savannas Preserve State Park (SPSP) was 19\% (an area of 5 ha). Economic valuations for the swine damage were based on the monetary amounts that wetland regulators have allowed permit applicants to spend in mitigation attempts to replace lost wetland resources. In 2003, the area of natural habitat damaged by swine had a total value of US\$ $1238760-4036290$. The SPSP implemented a contract for swine control throughout 2003 in all areas of the Park. The damage to the basin marsh was re-estimated in January 2004, after swine removal. The damage sampling transects remained the same as the 2003 survey, but damage was significantly reduced, with $31 \%$ of sampling transects showing damage in January 2004 versus $92 \%$ in January 2003. Similarly, the total area of swine damage had decreased to $0.95 \mathrm{ha}$, and the value of the lost habitat had been reduced to US\$235 355-766 865, an economic benefit of US\$ 1003 355-3 269265 . The benefit-cost ratio (BCR) relating the economic value of the damage reduction against the swine control costs (not all swine control in the park was carried out in the vicinity of the basin marsh) was conservatively estimated at 134-436. When estimating costs for swine control in the vicinity of the marsh based on the proportional number of swine removed there as compared to the Park as a whole, the BCR increased to 480-1562. Benefits of swine removal are very high relative to the costs of control.

Keymords: alien species, benefit cost analysis, damage estimation, economic value, exotic species, feral hogs, feral pigs, invasive species

\footnotetext{
* Correspondence: Dr Richard Engeman Tel: +1 9702666091 Fax:

+1 9702666089 e-mail: richard.m.engeman@aphis.usda.gov
}

\section{INTRODUCTION}

Feral swine (Sus scrofa) are a particularly destructive exotic species in many places around the world (see Seward et al. 2005). They negatively impact the environment through habitat degradation, predation on native species and competition with native species (Choquenot et al. 1996; Taft 1999). Swine were first introduced into the wild in North America in the 1500s in Florida (Towne \& Wentworth 1950), where today they flourish and cause widespread damage. Recent studies in south-eastern Florida have documented the levels of swine damage to increasingly rare natural habitats (Engeman et al. 2003, 2005). Those studies were also able to attach monetary costs on a per hectare basis to the habitat damaged by swine. One of the habitats studied was the last remnant of a formerly extensive basin marsh system, which is now located only within Savannas Preserve State Park (SPSP). In January 2003, swine damaged 19\% $(5 \mathrm{ha})$ of the exposed marsh, which was valued at US\$ 247 742-807 $226 \mathrm{ha}^{-1}$ (Engeman et al. 2005). This level of damage to such a fragile and rare habitat led the park to implement a swine control contract with USA Department of Agriculture/Wildlife Services (USDA/WS), the USA federal agency mandated to resolve human-wildlife conflicts. One year later, we revisited the basin marsh in SPSP to determine the biological and economical impacts of the management actions (swine control). We report on those results here.

\section{METHODS}

The SPSP protects the last remnant of the extensive freshwater basin marsh systems that formerly extended for about $320 \mathrm{~km}$ along Florida's east coast. Water levels fluctuate more dramatically on an annual basis in the SPSP basin marsh than in most basin marshes (Florida Department of Environmental Protection 2003). The basin marsh in the SPSP occurs in the form of a band $0.6-1.3 \mathrm{~km}$ wide immediately west of the Atlantic Coastal Ridge for the length of the property (approximately $15.5 \mathrm{~km}$ ). Within the 570 ha of basin marsh, a mixture of grasses and sedges in shallow open water dominates approximately $75 \%$ of the marsh, and sawgrass stands (Cladium jamaicense) cover the remaining $25 \%$. The ephemeral nature of the SPSP basin marsh results in the aquatic plant and animal communities 
being extremely sensitive to environmental disturbances. The fluctuating nature and gentle slope of the marsh also result in an exposed, wet margin, vegetated with forbs and grasses (Florida Natural Areas Inventory 1990), which is extremely attractive to foraging swine.

The USDA/WS contract was to remove feral swine in 2003 from all areas in SPSP, including around the basin marsh; this was primarily by using pen traps, which were relocated as each area was depleted of swine. Control in the vicinity of the basin marsh was carried out throughout most of 2003 . We defined 'vicinity' of the basin marsh as the trap locations where swine at those locations were almost certainly also visiting the basin marsh in our study area. Thus, swine caught in traps adjacent to the marsh and by game trails leading to the marsh were used in this count. The dates, numbers and sexes of swine removed were recorded.

\section{Study site and damage measurements}

In 2003, baseline damage was sampled at $100 \mathrm{~m}$ intervals for $5.9 \mathrm{~km}$ along the periphery of the basin marsh. Each sample site was marked with plastic flagging and a tape measure transect was placed along the perpendicular distance from the water's edge to the interface between the marsh and upland vegetation of the surrounding pine flatwoods community (Rodgers et al. 1996; Kautz 1987). Both of these limits to the exposed portion of basin marsh were abrupt and easy to define. After placing the tape measure, three damage measurements were made. The first was the total distance under the tape that was damaged by swine. This amount could represent a single patch of damage or the combined distances under the tape of multiple patches. Damage not lying directly under the tape was not recorded. Swine damage was defined as ground overturned during foraging (rooting) activity. Tracks verified the species responsible. Armadillos (Dasypus novemcinctus) were the only other species in the Park that could produce superficially similar (small) patches of damage, but these were easily distinguished from swine damage by track and digging characteristics (ground overturned by swine, or forefeet use by armadillos). The other two damage measures were binary and aimed at evaluating the damage precisely at the two habitat interfaces at the extremities of the transects. The point at which the tape contacted the water's edge was recorded as damaged or undamaged, as was the point at which the tape contacted the upland vegetation. The plastic flagging that marked the transects from the 2003 damage measurements was left in place and used to repeat the same damage measurements at the same locations in January 2004 after one year of control.

\section{Data analyses}

The per cent damaged at each sample site was calculated as the ratio of the distance along the tape that damage patches comprised, divided by the total distance between the two habitat interfaces. The per cent damaged along the basin marsh was calculated as the mean per cent damaged among the sample sites $(n=60)$. The total exposed area of the study area was calculated as the mean distance between habitat interfaces across the sample sites multiplied by the $5.9 \mathrm{~km}$ of shoreline. The damage rate along the shoreline was calculated as the per cent of sample sites with damage at the water's edge. The damage rate at the upland interface was calculated similarly. Cochran's Q test, for single-factor repeated measures designs with dichotomous data (see Winer 1971), was used to examine whether the rate of damage was different at the two habitat interfaces. The frequency of transects showing damage was compared between 2004 and 2003 using the same test. Using the same transect locations in 2004 as in 2003 allowed a mixed linear model (McLean et al. 1991; Wolfinger et al. 1991) to be used to compare damage levels between the years. SAS PROC MIXED (Littell et al. 1996) was used to carry out the analysis.

The 2003 study, like a prior study (Engeman et al. 2003), placed monetary value on swine damage by using expenditure data for permitted wetland mitigation projects in the USA. Such data provide empirical demonstrations and consequently the most credible estimates of willingness-to-pay values available (King 1998; Engeman et al. 2003, 2004), although these valuations might be considered conservative for habitats supporting endangered plants, as in the SPSP (Engeman et al. 2003). King (1998) presented the dollar amounts per unit area spent in efforts to restore a spectrum of wetland habitat types. The numbers represent the US\$ amounts that environmental regulators and, to a degree, elected governments have allowed permit applicants to spend in attempts to replace lost wetland services and values (King 1998). We used the same values identified in the 2003 baseline analysis (Engeman et al. 2005) for the appropriate wetland habitat category from each of the two studies in King (1998). For these two studies, the habitat from our study would be classified as 'freshwater emergent' or 'open-water emergent'. The respective empirical willingnessto-pay monetary values, adjusted for $3 \%$ inflation (Zerbe $\&$ Dively 1994) to 2003 US\$ were, respectively, US\$ 247 $742 \mathrm{ha}^{-1}$ and US\$ $807226 \mathrm{ha}^{-1}$. The cost of the total area in our study site damaged by swine was calculated by multiplying the above values by the estimated area of swine damage.

A benefit-cost analysis (BCA) was used to determine in monetary terms the net benefit of swine management relative to its cost (Boardman et al. 1996; Nas 1996; Zerbe \& Dively 1994). Reduction or abatement of loss of swine damaged habitat is seen as a benefit. In other words, if management action in the form of swine control reduced the amount of marsh habitat lost to swine damage, then the benefit of that management effort is the monetary value of that amount of habitat versus the costs of the effort. The BCA of the swine control involved estimating the benefit-cost ratio (BCR) of the monetary value of the benefits, measured as the value of the reduction in area of the marsh suffering swine damage from 2003 to 2004, versus the cost of the swine control. The equation to calculate BCRs can be written as:

$$
\begin{aligned}
\mathrm{BCR}= & {[(\mathrm{US} \$ \text { value of } 2003 \text { swine damage }} \\
& -\mathrm{US} \$ \text { value of } 2004 \text { swine damage })] \\
& \div \mathrm{US} \$ \text { cost of swine control }
\end{aligned}
$$




\section{RESULTS}

\section{Swine control}

Sixty-four swine (27 male, 37 female) were removed from the vicinity of the basin marsh in 2003. Swine were captured during the months of January (28), February (11), March (7), April (1), July (7), September (1), October (5), and December (12). This represents 27.9\% of the total of 229 swine that were removed from the entire Park between the 2003 and 2004 damage surveys.

\section{Damaged area}

The mean width of the exposed portion of the basin marsh in 2004 was $23.1 \mathrm{~m}(\mathrm{SE}=3.4 \mathrm{~m})$. Multiplying this value by the $5.9 \mathrm{~km}$ distance of marsh periphery sampled resulted in an estimated total area of exposed basin marsh in our study site of 13.6 ha in 2004. The 2004 damage level of $7 \%$ was found to be substantially less than the $19 \%$ damage found in 2003 $\left(F_{1,56.1}=18.78, p<0.0001\right)$. The $7.0 \%$ mean damage resulted in an estimate of 0.95 ha of exposed basin marsh damaged by swine.

The $31.0 \%$ of sample transects showing some damage in 2004 was a substantial (62.8\%) reduction from the $91.7 \%$ of transects that showed damage in $2003\left(\chi^{2} 1 \mathrm{df}=33.1, p<\right.$ $0.0001)$. Diminished damage rates at the basin marsh shoreline and upland habitat interfaces necessarily followed. Only $15.5 \%$ of the sites showed damage at the upland interface, which was a major reduction from $58.3 \%$ in $2003\left(\chi^{2} 1 \mathrm{df}=\right.$ $22.2, p<0.0001)$. Even more dramatic was the reduction in damage at the shoreline from $70.0 \%$ in 2003 to only $3 \%$ of sites in $2004\left(\chi^{2} 1 \mathrm{df}=39.0, p<0.0001\right)$. In contrast to 2003 (Engeman et al. 2005), the rates of damage between the upland and shoreline habitat interfaces were found to differ $\left(\chi^{2} 1 \mathrm{df}\right.$ $=5.44, p=0.02$ ).

\section{Economic analysis}

The value of the damage in 2004 was US $\$ 235355$ ('freshwater emergent' valuation) and US\$ 766865 ('open-water emergent' valuation). The value of the damage reduction from 2003 to 2004 was US\$ 1003355 ('freshwater emergent' habitat category) and US\$3 269265 ('open-water emergent' habitat category). We used these as the value of swine control benefits in the calculation of separate BCRs for each habitat category.

The total cost of the swine control contract for all of the SPSP in the interim between the 2003 damage survey and the post-control survey was US\$ 7500. The effort directed towards swine control around the basin marsh was an unmeasured subset of this total. Therefore, the BCA of the impacts of the control efforts on the basin marsh are conservative if the US\$7500 cost figure is used. Nevertheless, even these conservative BCRs were very high, namely 133.8 ('freshwater emergent' habitat category) and 435.9 ('openwater emergent' habitat category).
We can attempt to define the subset of costs for control of swine in the vicinity of the basin marsh if we assume the effort applied to different areas of SPSP is proportional to the swine captured in the different areas. Then, swine control in the vicinity of the basin marsh represented $27.9 \%$ (64 of 229 swine) of the total swine control effort in the Park. Thus, US\$ 2092.50 of the US $\$ 7500$ cost of the control contract was spent on protecting the basin marsh. The BCRs using this cost for the 'freshwater emergent' and 'open-water emergent' habitat categories were respectively 479.5 and 1562.4 .

\section{DISCUSSION}

As with many currently rare habitats, the once-extensive basin marsh system in Florida has been lost to development, and the relatively small remainder found in SPSP had been heavily damaged by swine. A year of swine control efforts was highly effective at reducing the rate of damage to this rare habitat, with the total area of damage to the marsh reduced from 5.0 ha to 0.95 ha. Importantly, from a management standpoint, the cost of the swine control was only a small fraction of the economic assessment of the benefits, even when using the more conservative habitat valuation figure and applying costs that include areas beyond the basin marsh.

The economics of feral swine damage and the benefits/costs of swine control have largely been explored relative to agricultural crops and livestock (for example see Tisdell 1982). A number of authors, primarily focused on Australian agricultural settings, have used the average cost per swine removed as a basis for evaluating and comparing costeffectiveness of swine control programmes (see Hone 1983; Korn 1986; Saunders \& Bryant 1988; Saunders et al. 1990; Saunders 1993). Australian inflation and the exchange rate versus the US\$ has been variable during 1983-2003, making current cost comparisons with our present study that reflect purchasing-power parity difficult. From those studies, helicopter shooting, a method unsuitable for a site such as the SPSP, which is surrounded by urban development, was typically found to be more cost-effective than trapping, although trapping had been found to be the least expensive method when 46 or fewer swine were to be removed from medium to high densities (Turvey 1978). The cost effectiveness of two recent aerial hunting efforts for swine in Australia (Lapidge et al. 2004) can be more directly comparable with our results than the older studies. The 2003 costs per swine removed reported by Lapidge et al. (2004) for the two aerial hunting efforts were AUS\$ 76 and AUS\$ 69. Assuming that purchasing-power parity holds via exchange rate, and there are no transaction costs or official barriers to trade, we can apply an approximate $0.7 \mathrm{US} \$$ / AUS\$ exchange rate to arrive at costs of US\$ 53 and US\$ 48, respectively, per swine removed (Krugman \& Obstfeld 2000).

For SPSP, we are also in a position to evaluate the economics of swine control for habitat protection on the basis of benefit per swine removed. If we assign the total US\$ 7500 contract cost to the 64 swine removed in the vicinity of the basin 
marsh, then the cost per swine removed would be US\$ 117 . However, if we assign the cost for swine control proportional to the numbers of swine removed in the vicinity of the marsh compared to the Park at large, then the cost per swine removed is US\$33, which is lower than the recent figures for aerial shooting in Australia (Lapidge et al. 2004). The benefit per swine removed is the value of the damage reduction divided among (averaged over) the swine removed. Thus, the economic benefit per swine removed when using the 'freshwater emergent' habitat valuation was US\$ 15677 per swine and the benefit when using the 'open-water emergent' valuation was US\$ 51087 per swine. Either figure presents a dramatic picture of the cost effectiveness of swine control.

Choquenot and Hone (2002) used bioeconomic simulation models to estimate benefit-cost ratios for controlling feral swine to reduce predation on lambs. Depending on the control method and modelling assumptions, their resulting BCRs for swine control were as high as 35 . Our empirical results based on known costs and the value of the damaged rare habitat provided BCRs that were on average at least ten-fold higher, ranging from 133.8 to 1562.4 , depending on whether the total or marsh-proportion of the contract were applied as the cost, and whether the 'freshwater emergent' or the 'openwater emergent' wetland characterization of the habitat were applied.

SPSP might be considered a viable candidate for swine eradication based on the criteria set forth by Bomford and O'Brien (1995) for successful eradication. Briefly, SPSP is completely encapsulated in suburban development, making natural immigration unlikely. Through damage and spoor, swine populations in the Park's habitats are detectable and can be indexed after severe population reductions (Engeman et al. 2001, 2003). Potentially reproductive females comprised the largest subset of the swine removed ( 24 of $64,37.5 \%$ ), indicating high risk to these animals from the control methods. This, combined with a lack of immigration, suggests that animal removal would exceed population increases at all densities. Despite potentially satisfying sufficient of the criteria set out by Bomford and O'Brien (1995) for eradication, the length of time and the concomitant funding needed for complete swine removal from SPSP are uncertain, as is the future availability of funds to complete such an endeavour. Undoubtedly, the cost per swine removed would increase as the population nears eradication. Therefore, significant population and damage reductions were the aims of the control effort, with eradication a desirable outcome if it occurs.

In Florida, a premium is placed on sanctuaries for protection and preservation of habitats and species, especially because much of the natural habitat in Florida has already been lost to development. Feral swine are a very common exotic species in Florida that impact rare habitats and species throughout the state. Prior studies have demonstrated that even seemingly low levels of swine damage to habitat can still represent a major economic cost (Engeman et al. 2003), and greater damage levels naturally result in greater relative costs (Engeman et al. 2005). The present study carries the resource and corresponding economic evaluation to the next step by demonstrating relatively quick positive impacts to a rare Florida habitat from feral swine control, and that the benefits of the control are extremely high in comparison to the costs of the control.

\section{ACKNOWLEDGEMENTS}

K. Fagerstone and J.R. Mason provided insightful reviews of earlier drafts of this manuscript.

\section{References}

Boardman, A.E., Greenberg, D.H., Vining, A.R. \& Weimer, D.L. (1996) Cost-Benefit Analysis: Concepts and Practice. Upper Saddle River, NJ, USA: Prentice Hall: 493 pp.

Bomford, M. \& O'Brien, P. (1995) Eradication or control for vertebrate pests? Wildlife Research 23: 249-255.

Choquenot, D. \& Hone, J. (2002) Using bioeconomic models to maximize benefits from vertebrate pest control: lamb predation by feral pigs. In: Human Conflicts with Wildlife, ed. L Clark, pp. 6579. Fort Collins, CO, USA: US Department of Agriculture/ APHIS/WS/NWRC.

Choquenot, D., McIlroy, J. \& Korn, T. (1996) Managing Vertebrate Pests: Feral Pigs. Canberra, ACT, Australia: Bureau of Resource Sciences, Australian Government Publishing Service: 163 pp.

Engeman, R.M., Constantin, B., Nelson, M., Woolard, J., Bourassa, J. (2001) Monitoring changes in feral swine population and spatial distribution of activity. Environmental Conservation 28: 235-240.

Engeman, R.M., Shwiff, S.A., Smith, H.T. \& Constantin, B.U. (2004) Monetary valuation of rare species and imperiled habitats as a basis for economically evaluating conservation approaches. Endangered Species Update 21: 66-73.

Engeman, R.M., Smith, H.T., Severson, R., Severson, M.A., Shwiff, S.A., Constantin, B.U. \& Griffin, D. (2005) The amount and economic cost of feral swine damage to the last remnant of a basin marsh system in Florida. Fournal for Nature Conservation (in press).

Engeman, R.M., Smith, H.T., Shwiff, S.A., Constantin, B.U., Nelson, M., Griffin, D. \& Woolard, J. (2003) Prevalence and economic value of feral swine damage to native habitat in three Florida state parks. Environmental Conservation 30: 319-324.

Florida Department of Environmental Protection (2003) Savanas Preserve State Park Management Plan. Tallahassee, FL, USA: Florida Department of Environmental Protection, Florida Park Service: $34 \mathrm{pp}$.

Florida Natural Areas Inventory (1990) Guide to the Natural Communities of Florida. Tallahassee, FL, USA: Florida Natural Areas Inventory and Florida Department of Natural Resources: 111 pp.

Hone, J. (1983) A short term evaluation of feral pig eradication at Willandra in western New South Wales. Australian Wildife Research 10: 269-275.

Kautz, R (1987) Preliminary Cover Types for Landsat Inventory. Tallahassee, FL, USA: Florida Game and Freshwater Fish Commission, Office of Environmental Services, Nongame Wildlife Section. 
King, D. (1998) The dollar value of wetlands: trap set, bait taken, don't swallow. National Wetlands Nemsletter July-August: 7-11.

Korn, T. (1986) Use of helicopters for feral pig control. In: Proceedings of 10th National Noxious Plants and Animals Conference, ed. D. Brown, pp. 45-50 Orange, NSW, Australia: NSW Agriculture.

Krugman, P. \& Obstfeld, M. (2000) International Economics: Theory and Policy, Sixth Edition. Reading, MA, USA: Pearson, Addison, Wesley, Longman: $750 \mathrm{pp}$.

Lapidge, S.J., Cowled, B. \& Smith, M. (2004) Ecology, genetics, and socio-biology: practical tools in the design of target-specific feral pig baits and baiting procedures. Vertebrate Pest Conference 21: (in press).

Littell, R.C., Milliken, G.A., Stroup, W.W., Wolfinger, R.D. (1996) SAS System for Mixed Models. Cary, NC, USA: SAS Institute.

McLean, R.A., Sanders, W.L. \& Stroup, W.W. (1991) A unified approach to mixed linear models. The American Statistician 45: $54-64$.

Nas, T.F. (1996) Cost-Benefit Analysis: Theory and Application. CA, USA: Sage Publications.

Rodgers, J.A., Kale, H.W. \& Smith, H.T. (1996) Major habitats of Florida. In: Rare and Endangered Biota of Florida. Volume V: Birds, ed. R.E. Ashton. pp. xix-xxxii. Gainesville, FL, USA: University Presses of Florida.

Saunders, G. (1993) Observations on the effectiveness of shooting feral pigs from helicopters. Wildlife Research 20: 771776.
Saunders, G. \& Bryant, H. (1988) The evaluation of a feral pig eradication program during a simulated exotic disease outbreak. Australian Wildlife Research 15: 73-81.

Saunders, G., Kay, B. \& Parker, B. (1990) Evaluation of a warfarin poisoning programme for feral pigs (Sus scrofa). Australian Wildlife Research 17: 525-533.

Seward, N., VerCauteren, K. Witmer, G. \& Engeman, R. (2005) Feral swine impacts on agriculture and the environment. Sheep and Goat Research Fournal (in press).

Taft, A.C. (1999) Feral swine-national concerns. In: Proceedings of the 1999 National Feral Swine Symposium, pp. 25-26. Austin, TX, USA: Texas Animal Health Commission.

Tisdell, C.A. (1982) Wild Pigs: Environmental Pest or Economic Resource? Sydney, NSW, Australia: Pergamon Press.

Towne, C.W. \& Wentworth, E.N. (1950) Pigs from Cave to Cornbelt. Norman, OK, USA: University of Oklahoma Press:305 pp.

Turvey, R. (1978) Approaches to the selection of optimal control strategies for feral pigs: cost effectiveness analysis of present control measures. B. Agric. Econ. thesis, University of New England, Armidale, NSW, Australia.

Winer, B.J. (1971) Statistical Principles in Experimental Design. New York, NY, USA: McGraw-Hill.

Wolfinger, R.D., Tobias, R.D. \& Sall, J. (1991) Mixed models: a future direction. In: Proceedings of the 16th SAS Users Group Conference, pp. 1380-1388. Carey, NC, USA: SAS Institute.

Zerbe, R.O. \& Dively, D.D. (1994) Benefit-Cost Analysis: In Theory and Practice. New York, NY, USA: HarperCollins College Publishers. 